УДК 343.914

DOI https://doi.org/10.32849/2663-5313/2020.10.44

\title{
Тетяна Продан,
}

канд. юрид. наук,

асистент кафедри кримінального права

Чернівеиького національного університету імені Юрія Федьковича

\section{ФАКТОРИ, ЩО ВПЛИВАЮТЬ НА ФОРМУВАННЯ ЗЛОЧИННОЇ ПОВЕДІНКИ ЖІНОК}

У статті автором на підставі проведеного аналізу встановлено, що на процес формування злочинної поведінки жінок впливають безліч суб'єктивних (внутрішніх) та об'єктивних (зовнішніх) факторів. Фактори, які впливають на формування злочинної поведінки жінок, можна поділити на такі групи: фізичні (температура повітря, дратівливі звуки, тиша); біологічні (спадкова агресивність, хвороба); сочіальні (сім'я, виховання, освіта, культура, рівень матеріального забезпечення); психологічні (стрес, фрустрачія, стан афекту, настрій, стан алкогольного сп'яніння). Аргументовано, що центральне місие у формуванні злочинної поведінки жінок відводиться саме внутрішнім факторам. Акиентується увага на тому, що на процес прийняття рімення та переробки інформаиії впливають фактори різного характеру. Залежно від індивідуальних особливостей особи та конкретної ситуаціі сприйняття фактори можуть сприяти формуванню злочинної волі у жінок. У свою чергу, на виникнення злочинного мислення можуть впливати фактори, які мають глибші корені, ніж це здається на перший погляд: закладення злочинного мислення у жінки може відбуватися ще у юному віші, а проявитися вже у зрілих роках. Зазначено, що одним із основних факторів, що впливає на формування злочинного мислення та подальшої злочинної поведінки жінок, є первинне мікросочіальне оточення, а саме ї̈ сім'я. Дитина на прикладі взаємин між членами родини навчається поведінки та форм відносин, які зберігаються у неї в підлітковому вічі та в зрілі роки. Неправильне виховання в дитинстві, несприятливі умови та конфлікти у сім'ї ведуть до певних відхилень у психіці особистості, які підвишують можливість злочинної поведінки у жінки у зрілі роки. Встановлено, що злочинна поведінка жінки не може існувати без факторів, які впливають на формування у неї злочинного мислення та злочинної волі.

Ключові слова: фактори, жінка-злочинниця, злочинна поведінка, суб’єктивні фактори, об'єктивні фактори.

Постановка проблеми. Кримінологічна оцінка того чи іншого виду злочинності неможлива без встановлення особливостей поведінки злочинця до, під час і після вчинення суспільно небезпечного діяння. Така інформація дозволяє працівникам правоохоронних органів встановити наявність або відсутність необхідних складників об'єктивної та суб'єктивної сторони складу кримінального правопорушення, а також обрати максимально ефективне та співрозмірне покарання. Варто зазначити, що кожен вид злочинності є індивідуальним і зумовлений низкою рис і властивостей, які дозволяють його виокремити серед інших. Якщо говорити узагальнено, то вся зазначена нами інформація є своєрідним механізмом злочинної поведінки, тож вважаємо за доцільне більш детально зупинитися на факторах, які впливають на формування злочинної поведінки жінок.

Сьогодні фактори, що впливають на злочинну поведінку жінок, розглядалися такими вченими, як: В.В. Бедь, А.Б. Блага,
B.M. Бурлаков, А.П. Закалюк, I.I. Карпець, А.М. Корягіна, Н.П. Краснова, М.Д. Левітов, В.О. Меркулова, В.П. Салтиков, О.Л. Старко, B.В. Федусик та ін. Однак комплексного дослідження факторів, які вливають на формування злочинної поведінки жінок, не проводилося

Метою статті $є$ розкриття особливостей факторів, що впливають на формування злочинної поведінки жінки, крізь призму іiї етапів.

Виклад основного матеріалу. Злочинна поведінка жінки включає в себе об'єктивні (зовнішня) та суб'єктивні (внутрішня сторона злочину) фактори. Враховуючи, що суб'єктивні фактори $є$ провідними у злочинній поведінці жінки, пропонуємо розпочати наше дослідження саме 3 них.

Одним із факторів, який впливає на рівень формування злочинної поведінки жінки, є первинне мікросоціальне оточення - сім'я. Так, як зазначають Р. Берон і Д. Річардсон, саме в сім'ї особа проходить 
первинну соціалізацію. Вони стверджують, що на прикладі взаємин між членами родини дитина навчається поведінки і форм відносин, які зберігаються у неї в підлітковому періоді й у зрілі роки. Реакції батьків на неправильну поведінку дитини, характер відносин між батьками та дітьми, рівень сімейної гармонії чи дисгармонії, характер взаємин із рідними братами чи сестрами ось фактори, що можуть зумовлювати агресивну поведінку дитини у сім'ї і поза нею, а також впливати на їі відносини з оточуючими у зрілі роки $[1$, с. 93]. Також саме за низького рівня виховання в особи більше шансів вчинити злочин у майбутньому. Зокрема, як стверджує О.Л. Старко, відсутність емоційних контактів дитини 3 батьками зумовлює психологічне відчуження індивіда, що закладає основу подальшої дезадаптації. Відчуження може протікати відкрито (побої, образи, відсутність елементарної уваги та піклування) та приховано при зовнішній увазі, зазвичай жорстокому контролі, що виключає наявність емоційних контактів [2, с. 82]. А тому неправильне виховання в дитинстві, несприятливі умови, конфлікти у сім'ї ведуть до певних відхилень у психіці особистості, які підвищують можливість злочинної поведінки в особи у зрілі роки. Дівчинка, яка виховується у неповній або нещасливій родині, в якій батьки зайняті виключно своїми проблемами та потребами, зростає закомплексованою та замкненою в собі жінкою. Негативний приклад чоловіка у вигляді її власного батька спричиняе недовіру до осіб протилежної статі. Роль жертви, яку може виконувати іï матір, вона дублює на себе. Всі ці чинники призводять до фрустрації та формують у ній комплекс руйнуючих якостей, через які вона не може реалізувати себе у суспільстві та стає більш агресивною, прагне домінування. Це закладає першу цеглинку у створенні потенційної злочинниці.

Bсе це можна пояснити тим, що, якщо тривожність досягає рівня страху, людина починає захищати свій біологічний статус, своє існування, зокрема шляхом вчинення насильницьких злочинів як способу захисту від зовнішнього світу. Спеціальними кримінологічними дослідженнями встановлено, що найбільш характерними рисами вбивць $€$ підвищена сприйнятливість, очікування погрози з боку середовища. Якщо тривожність зберігається на рівні постійного занепокоєння та невпевності, то людина може захищати свій статус, соціальне існування шляхом вчинення корисливих і корисливонасильницьких злочинів. Шлях заспокоєння для такої особи - вживання алкоголю, нар- котичних чи інших психоактивних речовин або вчинення насильства проти особи, яка виступає збудником. Поєднання ж наркотиків і насильства виливається у насильницький злочин [2, с. 36]. В окремих дослідженнях наводяться дані, згідно 3 якими у родинах насильницьких злочинців діти у сім разів частіше, ніж у родинах корисливих, відчували байдужість до себе, розуміли, що ними тяготяться, їх майже вдвічі частіше зайве контролювали, нав'язували свою волю й карали. Кожен п'ятий насильницький злочинець був до матері байдужий або ставився до неї негативно. Більшість насильницьких злочинців визнають, що батьки в дитинстві піддавали їх фізичним покаранням, більше $40 \%$ зазначили, що їх били періодично або постійно, а майже $20 \%$ - що били сильно [2, с. 32]. Отже, насильство породжує насильство. Дитина, особливо дівчинка, є слабкою особою з несталою психікою та повною відсутністю уявлень про те, що дозволено, а що ні. Постійне почуття своєї провини (інколи незначної, але такої, що викликає агресію з боку близьких осіб) формує в ній віктимні настанови, котрі як наслідок роблять їі більш жорстокою та мстивою, а тому негативний вплив оточуючих надалі викликатиме в жінці прагнення проявити свою силу та захистити себе будь-яким шляхом.

Іншим фактором, що може впливати на підвищений рівень антигромадської та подальше формування злочинної поведінки, є низький рівень освіти й культури. Так, саме освіта, на нашу думку, впливає на формування в особистості $1 і ̈$ життєвих установок та інтересів. Зокрема, низький рівень освіти, недостатній розвиток культури зумовлюють значне звуження інтересів особи [2, c. 64]. С. Бакстер (S. Baxter) зазначає, що чим освіченіша жінка, чим вища кваліфікація iï праці, тим більш характерна для неї миролюбність [3, с. 59]. А звідси ми робимо висновок, що жінка, яка має вищу освіту, вчиняє злочин набагато рідше, ніж жінка з низьким рівнем освіти. В освіченішої жінки рівень злочинного мислення набагато нижчий, тож і менше шансів, що за наявності певної потреби у такої особи сформується злочинне мислення. Як зазначає О.Л. Старко, часткова відсутність знань, низький загальнокультурний рівень розвитку i, як наслідок, духовний «недорозвиток», що відобразився і на уявленнях про життєвий уклад, а саме сімейнопобутові відносини [2, с. 64], - один із факторів, який впливає на формування злочинного мислення і вчинення злочину. До того ж, низький рівень культури призводить до низького рівня культури взаємин у сім'ї між чоловіком і жінкою. Як наслідок, це призводить 
до систематичного фізичного, психічного насилля та до виникнення злочинного мислення і вчинення злочину жінкою.

Ще одним фактором може виступати низький рівень матеріального забезпечення жінки, що зумовлюється безробіттям і породжує відсутність життєвих перспектив, тобто неможливість задовольнити свої матеріальні потреби. Це викликає почуття невпевненості, тривожності, побоювання за своє існування. Як наслідок, такі почуття пригнічують всі психічні процеси жінок, розум і породжують несвідомий страх [2, с. 79]. Звідси ми робимо висновок, що всі ці обставини можуть впливати на формування злочинного мислення - жінки вчиняють злочин, щоб забезпечити своє існування.

Отже, як бачимо, на виникнення злочинного мислення можуть впливати безліч факторів, які мають глибші корені, ніж це здається на перший погляд. Закладення злочинного мислення в особи може відбуватися ще у юному віці, а проявитися вже у зрілих роках.

Однак для безпосереднього задоволення своєї потреби злочинним шляхом, підтриманої необхідною ситуацією, недостатньо лише того, щоб у особи було злочинне мислення. У механізмі злочинного поведінкового акту центральне місце займає злочинна воля. Саме вольові процеси відповідають за актуалізацію планів і перехід від психічного стану особистості до конкретних вчинків. Слід зазначити, що під час вольового процесу вже встановлюється та продовжує аналізуватися злочинний спосіб активного поведінкового акту, визнаний шляхом мислення як доцільний. Злочинне мислення $\epsilon$ передумовою формування злочинної волі в особи. Проте це ще не свідчить, що у особи цілком присутня злочинна воля, оскільки на іï̈ формування впливають і інші етапи вольового процесу. На формування злочинної волі в особи, як і на інші етапи злочинної поведінки, впливають певні фактори. Зокрема, як зазначає А.П. Закалюк, їх можна поділити на три групи: 1) ті, що прискорюють прийняття рішення та його реалізацію (сильне душевне хвилювання, стан алкогольного сп'яніння та ін.); 2) ті, які гальмують прийняття та реалізацію рішення (страх, переживання, невпевненість); 3) ті, що спрощують ставлення до значущості та небезпечності злочину, власних дій - алкогольне сп'яніння, доведення до істерії, активізація психопатії, інших психічних аномалій, невропатій [4, с. 311-312]. Також, на нашу думку, можна виділити ще й такі фактори, які впливають на формування злочинної волі в особи, як: настрій, стрес, емоційне напруження, фру- страція та ряд інших. Зокрема, розглянемо детальніше деякі з них.

Одним із факторів, що прискорює та спрощує прийняття рішення, є стан алкогольного сп'яніння. Так, вживання алкоголю жінками пояснюється тим, що вони шукають засобів заспокоєння, зняття постійного стресу через вживання спиртних напоїв, а це призводить натомість не лише до швидкої деградації, а й до проявів жорстокості [5, с. 95], до низького самоконтролю, нездатності керувати стресовими ситуаціями, тим самим створюючи підстави, на яких успішно розвиваються різні патологічні способи реагування і сприйняття [6, с. 483]. Таким чином, вживання алкоголю як провокуючий фактор за збігу певних обставин може слугувати фактором, що може вплинути на формування злочинної волі та подальше вчинення злочину.

Іншим фактором, який може вплинути на формування злочинної волі, є стрес. Стрес виникає при небезпеці, що викликана значним за силою подразником, адекватна реакція на який раніше не сформована, але повинна бути знайдена в ситуації, що склалася [7, с. 101]. До того ж, стрес, на нашу думку, може виникати за різних фізичних та інтелектуальних переживань. У жінки, яка перебуває у стані стресу, що підкріплений потребою, ситуацією та злочинним мисленням, може сформуватися злочинна воля.

Ще одним фактором є стан афекту, який викликається несподіваним чи дуже сильним подразником, до якого особа одразу не може пристосуватися. Так, стан афекту може виникнути у жінки внаслідок конфлікту між нею та потерпілим / потерпілою, довготривалої неуваги до прохання з боку потерпілого, фізичного насилля і призвести до формування злочинної волі.

Також, на нашу думку, можна виділити і такий фактор, як фрустрація. М.Д. Левітов визначає фрустрацію як психічний стан, що виражається в характерних особливостях переживання і поведінки та викликаний об'єктивно нездоланними труднощами, які виникають на шляху до досягнення цілі чи до вирішення задачі [8, с. 120]. Стан фрустрації супроводжується різними негативними переживаннями: розчаруванням, роздратованістю, тривогою, відчаєм, апатією, а тому жінка у стані фрустрації може виявляти агресивність, що може призвести до конфліктної ситуації та до формування злочинної волі. На формування останньої може впливати і настрій особи, змінюючись під впливом низки чинників. Це можуть бути як фізичні (холод, спека, дратівливі звуки та ін.), так і мікросоціальні фактори (образи, грубість, неуважність із боку потерпілого). Оскільки 
настрій впливає на проходження психічних процесів і діяльність особи, то можна говорити про те, що всі негативні риси настрою можуть впливати на формування злочинної волі у такої особи.

Таким чином, на процес прийняття рішення і переробки інформації впливають безліч факторів. Залежно від індивідуальних особливостей особи та конкретної ситуаціі сприйняття фактори можуть бути більшменш глибокими і сприяти формуванню злочинної волі.

\section{Висновки.}

Підбиваючи підсумок викладеного, слід зазначити, що на формування злочинної поведінки жінки впливають безліч зовнішніх і внутрішніх факторів. Всі ці фактори можна поділити на чотири великі групи: соціальні, біологічні, психологічні та фізичні. До соціальних можна віднести: сім'ю, виховання, освіту, культуру, рівень матеріального забезпечення. До біологічних - спадкову агресивність, різні хвороби До психологічних - стрес, фрустрацію, стан афекту, настрій, стан алкогольного сп'яніння. До фізичних - температуру повітря, дратівливі звуки, тишу тощо. Наведені фактори є підгрунтям актуалізації потреб жінок, які задовольняються злочинним шля- хом, і підгрунтям формування злочинного мислення та злочинної волі у жінок. Отже, етапи злочинної поведінки жінки не можуть існувати без цих факторів.

\section{Список використаних джерел:}

1. Бэрон Р., Ричардсон Д. Агрессия. СанктПетербург : Издательство «Питер», 1999. 352 с.

2. Старко О.Л. Умисне вбивство матір'ю своєї новонародженої дитини (кримінально-правове та кримінологічне дослідження) : монографія. Луцьк : Волин. Нац. ун-т ім. Лесі Українки, 2009. $188 \mathrm{c}$.

3. Baxter S. Women and Politics. The visible majority. University of Michigan Press, 1983. P. 59.

4. Закалюк А.П. Курс сучасної української кримінології: теорія і практика : у 3 кн. Київ : Видавничий Дім «Ін Юрє», 2007. Кн. 1: Теоретичні засади та історія української кримінологічної науки. $424 \mathrm{c}$.

5. Краснова Н.П. Особливості процесу виховання засуджених жінок. Соиіальна педагогіка: теорія та практика. 2012. № 3. С. 94-102.

6. Криминология: XX век / под ред. В.Н. Бурлакова, В.П. Салтыкова. Санкт-Петербург : «Юридический центр Пресс», 2000. 554 с.

7. Бедь В.В. Юридична психологія : навчальний посібник. Київ : МАУП, 2004. 436 с

8. Левитов Н.Д. Фрустрация - один из видов психических состояний. Вопросы психологии. 1967. № 6. C. 117-125.

\section{Tetiana Prodan. Factors influencing the formation of criminal behavior of women}

In the article, the author based on the analysis found that the process of formation of criminal behavior of women is influenced by many subjective (internal) and objective (external) factors. It is established that the factors influencing the formation of women's criminal behavior can be divided into the following groups: physical (air temperature, annoying sounds, silence); biological (hereditary aggression, disease); social (family, upbringing, education, culture, level of material security); psychological (stress, frustration, state of affect, mood, state of intoxication). It's argued that the central place in the formation of criminal behavior of women is given to internal factors. Emphasis placed on the fact that the decision-making process and information processing are influenced by various factors. It's noted that depending on the individual characteristics of the person and the specific situation, the perception of factors may contribute to the formation of criminal will in women. In turn, it was found that the emergence of criminal thinking can be influenced by factors that have deeper roots than it seems at first glance, namely the level of criminal thinking in women can occur at a young age, and manifest itself in adulthood. It's noted that one of the main factors influencing the formation of criminal thinking and subsequent criminal behavior of women is the primary microsocial environment, namely her family. On the example of relationships between family members, the child learns the behavior and forms of relationships that are maintained in adolescence and adulthood. Therefore, improper upbringing in childhood, unfavorable conditions and conflicts in the family lead to certain deviations in the psyche of the individual, which in turn increase the possibility of criminal behavior in women in adulthood. It's established that a woman's criminal behavior cannot exist without factors influencing the formation of criminal thinking and criminal will in her.

Key words: factors, female offender, criminal behavior, subjective factors, objective factors. 